\title{
ВЛИЯНИЕ ГЕНОТИПОВ ПО ДНК-МАРКЕРАМ НА ВОСПРОИЗВОДИТЕЛЬНЫЕ КАЧЕСТВА СВИНЕЙ ПОРОД КРУПНАЯ БЕЛАЯ И ЛАНДРАС
}

\author{
Е.Е. МЕЛЬНИКОВА, Н.В. БАРДУКОВ, М.С. ФОРНАРА, О.В. КОСТЮНИНА, \\ А.А. СЕРМЯГИН, G. ВREM, Н.А. ЗИНОВЬЕВА
}

Скорость генетического прогресса по низконаследуемым признакам воспроизводства у свиней может быть увеличена за счет интеграции в селекционные программы ДНК-маркеров, ассоциированных с локусами количественных признаков (QTL) репродуктивных качеств (маркерная селекция, marker-assisted selection, MAS). В представленной работе впервые получены результаты, указывающие на отсутствие значимого влияния гена IGF2 на фертильность свиноматок. Сопряженность генов $E C R$ F18/FUT1, ESR и MUC4 с оценками племенной ценности по собственной продуктивности свиноматок оказалась значимой и подтверждала взаимосвязь генетических и физиологических механизмов формирования репродуктивных особенностей свиней. Целью настоящих исследований была оценка влияния ДНК-маркеров IGF2 (инсулиноподобный фактор роста 2), ECR F18/FUT1 (рецептор Escherichia coli F18), ESR (эстрогеновый рецептор) и MUC4 (муцин 4) на признаки фертильности свиноматок пород крупная белая и ландрас. Материалом служили данные первичного учета показателей воспроизводительных качеств по результатам первых трех опоросов свиноматок (Sus scrofa) пород крупная белая $(n=894)$ и ландрас $(n=513)$ в ООО «Селекционно-гибридный центр» (Воронежская обл.). Были проанализированы абсолютные значения и скорректированные фенотипические показатели, а также проведена оценка племенной ценности особей (Estimated Breeding Value, EBV) по следующим признакам: число рожденных поросят в гнезде за один опорос (TNB), число живорожденных поросят за один опорос (NBA), средняя масса поросенка в гнезде при рождении (BW), скорректированная масса поросенка в гнезде при рождении (BW $\left.{ }_{\text {adj}}\right)$, молочность свиноматки (масса гнезда при отъеме на 21-е сут) (WW), скорректированная молочность свиноматки (скорректированная масса гнезда при отъеме на 21-е сут) (WW набора реагентов ДНК-Экстран-2 (ООО «НПФ Синтол», Россия). Были определены частоты встречаемости генотипов по анализируемым маркерам и выявлены их достоверные отклонения от состояния популяционного равновесия для животных крупной белой породы по гену $I G F 2(\mathrm{p}<0,01)$ и породы ландрас по генам IGF2 (р < 0,01), ECR F18/FUT1 (р < 0,01) и MUC4 (р < 0,001). Значение коэффициента гомозиготности по Робертсону (Са) было наибольшим для генотипов по генам IGF2 и $E C R$ F18/FUT1, при этом для особей крупной белой породы показатель достигал соответственно 0,76 и 0,65 против 0,60 и 0,72 для породы ландрас. Коэффициенты наследуемости анализируемых признаков для двух пород варьировали в следующих пределах: TNB - 0,1650,179, NBA - 0,100-0,155, BW - 0,232-0,338, WW - 0,010-0,115. На основе разработанных уравнений были определены значения племенной ценности свиней по методу BLUP AM. По маркеру IGF2 установлено достоверное влияние $(\mathrm{p}<\mathrm{0,05})$ на показатели молочности свиноматок породы ландрас $\left(\mathrm{PHE}_{W W}, \mathrm{PHE}_{W W a d j}, \mathrm{EBV}_{W W}\right)$, лучшими оказались особи с генотипами $\boldsymbol{A A}$ и $\boldsymbol{A G}$. Генотип по маркеру $E C R$ F18/FUT1 достоверно влиял $($ р $<0,05)$ на фенотип и племенную ценность свиней по числу рожденных поросят и по средней массе поросят при рождении. Свиноматки с генотипом $\boldsymbol{A A}$ характеризовались меньшим числом рождаемых поросят (на 8,0-8,5 \%) и более высокой их средней массой при рождении (на 2,0-3,0 \%). Выявлено достоверное влияние маркера $E S R$ на TNB и NBA и на значения EBV для признака «средняя масса поросят при рождении» $(p<0,05)$. По признаку «средняя масса поросенка при рождении» лучшими показателями характеризовались свиноматки обеих пород с генотипом $C$. Маркер MUC4 оказался значимыми фактором для признака «средняя масса поросят при рождении» для животных обеих пород $(F-$ критерий достоверен при р $<0,05)$. Свиноматки с генотипами $C C$ и $C G$ превосходили особей, гомозиготных по аллелю $G$. Таким образом, использование подходов маркерной селекции наряду с традиционными методами оценки генетического потенциала свиней позволит существенно повысить эффективность селекции по признакам фертильности.

Ключевые слова: свиньи, крупная белая порода, ландрас, IGF2, ECR F18/FUT1, ESR, $M U C 4$, линейная регрессия, признаки фертильности, оценка племенной ценности, маркерная селекция.

\footnotetext{
* При выполнении исследований использовалось оборудование ЦКП «Биоресурсы и биоинженерия сельскохозяйственных животных» ФНЦ ВИЖ им. академика Л.К. Эрнста. Исследования выполнены при поддержке Министерства науки и высшего образования Российской Федерации, уникальный номер проекта RFMEFI60417X0182.
} 
Улучшение воспроизводительных качеств - одна из основных целей селекции свиней материнских пород (1). Однако относительно невысокая наследуемость, значительная вариабельность и ограниченное полом проявление таких репродуктивных признаков свиноматок, как многоплодие, число и масса живых поросят при рождении и к отъему, молочность (2), ограничивают результативность традиционной селекции. Например, показатели коэффициентов наследуемости признаков фертильности у свиней крупной белой породы варьируют от 0,02 до 0,21 (3). В связи с этим интерес представляет интеграция в селекционные программы ДНК-маркеров, ассоциированных с локусами количественных признаков (quantitative trait loci, QTL) репродуктивных качеств свиней (маркерная селекция, marker-assisted selection, MAS) (4, 5). MAS облегчает реализацию существующего генетического разнообразия в размножающихся популяциях и может быть использована для улучшения желательных признаков (6).

Одним из первых ДНК-маркеров репродуктивных признаков (число живорожденных поросят), рекомендованных для включения в селекционные программы, был ген эстрогенового рецептора - ESR (7). Ассоциация этого ДНК-маркера с воспроизводительными признаками подтверждена многочисленными исследованиями как за рубежом (8-10), так и в нашей стране (11-13). Косвенное влияние на воспроизводительные качества свиней могут оказывать ДНК-маркеры ECR F18/FUT1 (рецептор Escherichia coli F18/FUT1), генетические варианты которого связывают с устойчивостью к послеотъемной диарее $(14,15)$, и $M U C 4$ (муцин 4) (16), генетические варианты которого ассоциированы с устойчивостью к колибактериозу $(17,18)$. Кроме того, современные программы генетического совершенствования свиней наряду с улучшением воспроизводительных качеств ориентированы на повышение показателей мясной и откормочной продуктивности. В этой связи находит применение целый ряд ДНК-маркеров, включая ген инсулиноподобного фактора роста 2 (IGF2). Использование $I G F 2$ обусловлено в первую очередь его патернальными свойствами (19) и влиянием на мясность свиней (20-22).

Важный аспект интеграции MAS в программы разведения свиней изучение возможного антагонистического действия ДНК-маркеров на разные продуктивные признаки. В литературе имеется недостаточно сведений о возможном отрицательном влиянии ДНК-маркеров мясных и откормочных признаков на воспроизводительные качества свиней, а также о негативном воздействии маркеров репродуктивных качеств на признаки мясной и откормочной продуктивности.

В представленной работе мы впервые провели анализ влияния группы генетических маркеров на детерминацию признаков воспроизводительных качеств у свиней материнских пород крупная белая и ландрас отечественной репродукции. Были получены результаты, указывающие на отсутствие значимого влияния гена IGF2 на фертильность свиноматок. Сопряженность генов ECR F18/FUT1, ESR и MUC4 с оценками племенной ценности по собственной продуктивности свиноматок оказалась значимой и подтверждала взаимосвязь генетических и физиологических механизмов формирования репродуктивных особенностей свиней.

Целью настоящей работы была оценка влияния ДНК-маркеров IGF2, ECR F18/FUT1, ESR и MUC4 на воспроизводительные качества свиноматок пород крупная белая и ландрас.

Методика. Исследования проводили в 2018-2019 годах. Материалом служили данные первичного учета показателей воспроизводительных качеств по результатам первых трех опоросов свиноматок (Sus scrofa) по- 
род крупная белая $(n=894)$ в период с 2008 по 2018 год и ландрас $(n=513)$ в период с 2010 по 2018 год в ООО «Селекционно-гибридный центр» (Воронежская обл.). Массив данных для свиноматок крупной белой породы (дочерей 66 хряков-отцов и 291 матки) составил 2250 записей (в среднем 2,52 опроса на свиноматку), для животных породы ландрас (дочерей 63 хряков и 503 маток) данные содержали 1360 записей (в среднем 2,65 опороса на свиноматку). Были проанализированы абсолютные значения и скорректированные фенотипические показатели, а также проведена оценка племенной ценности особей (Estimated Breeding Value, EBV) по следующим признакам: число рожденных поросят в гнезде за один опорос (TNB), число живорожденных поросят за один опорос (NBA), средняя масса поросенка в гнезде при рождении (BW), скорректированная масса поросенка в гнезде при рождении $\left(\mathrm{BW}_{\mathrm{adj}}\right)$, молочность свиноматки (масса гнезда при отъеме на 21-е сут) (WW), скорректированная молочность свиноматки (скорректированная масса гнезда при отъеме на 21-е сут) ( $\left.\mathrm{WW}_{\mathrm{adj}}\right)$. Распределение фенотипических данных по изученным признакам соответствовало закону нормального распределения.

Скорректированные фенотипические показатели для BW и WW pacсчитывали на основе оценки значимости влияния паратипических факторов согласно $F$-критерию Фишера по уравнениям линейной регрессии. К корректирующим факторам, предположительно влияющим на изменчивость анализируемых признаков, были отнесены: число живорожденных поросят в гнезде (NBA), число выкармливаемых свиноматкой поросят (число поросят в гнезде после пересадки) (NAT), число поросят в гнезде при отъеме (NW), продолжительность подсосного периода (PLP). При расчете корректированного показателя «молочность свиноматки» учитывался фактор NW в связи с более значимым показателем коэффициента детерминации, характеризующим линейность зависимости признака от анализируемого фактора. Влияние факторов на изменчивость признаков оценивали с использованием многофакторного дисперсионного анализа (ANOVA).

Уравнения линейной регрессии по двум породам для корректируемого признака BW ( $\mathrm{R}^{2}-$ коэффициент детерминации):

\begin{tabular}{lcc} 
корректируюший фактор & крупная белая порода & ландрас \\
\hline NBA & $\mathrm{y}=-0,03 \mathrm{x}+1,83, \mathrm{R}^{2}=0,23$ & $\mathrm{y}=-0,03 \mathrm{x}+1,84, \mathrm{R}^{2}=0,19$ \\
\multicolumn{4}{c}{ Уравнения линейной регрессии по двум породам для корректируе- } \\
мого признака WW: & крупная белая порода & ландрас \\
корректирующий фактор & $\mathrm{y}=2,01 \mathrm{x}+51,22, \mathrm{R}^{2}=0,14$ & $\mathrm{y}=1,11 \mathrm{x}+60,55, \mathrm{R}^{2}=0,054$ \\
NAT & $\mathrm{y}=7,12 \mathrm{x}+0,45, \mathrm{R}^{2}=0,55$ & $\mathrm{y}=6,60 \mathrm{x}+5,19, \mathrm{R}^{2}=0,48$ \\
NW & $\mathrm{y}=2,89 \mathrm{x}+4,41, \mathrm{R}^{2}=0,42$ & $\mathrm{y}=2,46 \mathrm{x}+13,22, \mathrm{R}^{2}=0,41$ \\
PLP &
\end{tabular}

Геномную ДНК выделяли из проб ткани (ушной выщип) с использованием набора реагентов ДНК-Экстран-2 (ООО «НПФ Синтол», Россия). Оценку качества и измерение концентрации ДНК проводили с помощью флуориметра Qubit 2.0 («Invitrogen»/«Life Technologies», США) и спектрофотометра NanoDrop8000 («Thermo Fisher Scientific», США).

Генотипы по ДНК-маркеру IGF2 (G $\rightarrow$ A в позиции 16144, Accession No. AY242112, GenBank, https://www.ncbi.nlm.nih.gov/genbank/) определяли, как описано Е.Е. Мельниковой и соавт. (22). Генотипы по ДНК-маркерам $E S R(\mathrm{GG} \rightarrow \mathrm{AT}$ в позициях 65-68, Accession No. HF947272.1, No. AY242112), $E C R(\mathrm{G} \rightarrow \mathrm{A}$ в позиции 915, Accession No. U70883.2) и MUC4 $(\mathrm{A} \rightarrow \mathrm{G}$ в позиции 243, Accession No. DQ848681) выявляли методом мультиплексной ПЦР с FLASH-детекцией (fluorescent amplification-based specific hybridization) по конечной точке с использованием системы высокопроизводитель- 
ного генотипирования Fluidigm EP1 («Fluidigm Corporation», США).

Были разработаны и апробированы модели для оценки влияния генотипов животных по исследуемым ДНК-маркерам на изменчивость абсолютных и скорректированных фенотипических показателей воспроизводства свиней по методу наименьших квадратов (Least Square Means, LSM) по следующему уравнению:

$$
\mathrm{y}=\mu+\mathrm{YMCG}+\mathrm{b}_{1} \mathrm{Par}+\mathrm{G}_{1}+\mathrm{e},
$$

где у - учитываемые фенотипические показатели по признакам TNB и $\mathrm{NBA}, \mu-$ популяционная средняя, YMCG - фактор влияния временно действующих условий среды «год-месяц-группа сравнения», ${ }_{1}$ Par - коэффициент регрессии и регрессионный фактор «номер опороса свиноматки», $\mathrm{G}_{1}$ - эффект генотипа по каждому из маркеров IGF2, ECR F18/FUT1, $E S R, M U C 4$, е - остаточные (неучтенные) эффекты модели. Включение в уравнение модели оценки фактора YMCG обосновано высоким значением достоверности влияния этого комплексного показателя на изменчивость всех анализируемых признаков животных обеих пород $(F$-критерий фактора значим при $\mathrm{p}<0,01)$, что подтверждает существенное влияние паратипических эффектов на изменчивость признаков воспроизводства у свиней. Для крупной белой породы по фактору YMCG было сформировано 115 групп (в среднем 19,6 записи в группе); для породы ландрас - 163 группы (в среднем 8,3 записи).

Племенную ценность (EBV) животных оценивали согласно методологии BLUP Animal Model, учитывающей наличие родственных связей, используя в расчете аддитивную матрицу родства.

Уравнения модели были следующими: для признаков TNB и NBA: $\mathrm{y}=\mu+\mathrm{YMCG}+\mathrm{b}_{1} \mathrm{Par}+$ animal $+\mathrm{e}$,
для признака BW: $\mathrm{y}=\mu+\mathrm{YMCG}+\mathrm{b}_{1} \mathrm{Par}+\mathrm{b}_{2} \mathrm{NBA}+$ animal $+\mathrm{e}$,
для признака WW: $\mathrm{y}=\mu+\mathrm{YMCG}+\mathrm{b}_{1}$ Par $+\mathrm{b}_{2} \mathrm{PLP}+$ animal $+\mathrm{e}$,

где у - абсолютные фенотипические показатели, $\mu-$ популяционная средняя для признаков TNB и NBA [2], BW [3], WW [4], YMCG - фактор влияния временно действующих условий среды «год-месяц-группа сравнения», $\mathrm{b}_{1}$ Par - коэффициент регрессии и регрессионный фактор «номер опороса свиноматки», $\mathrm{b}_{2} \mathrm{NBA}-$ коэффициент регрессии и регрессионный фактор «количество живорожденных поросят за один опорос», ${ }_{2}$ PLP коэффициент регрессии и регрессионный фактор «продолжительность подсосного периода», animal - аддитивный генетический эффект животного, е - остаточные (неучтенные) эффекты модели.

Коэффициенты наследуемости рассчитывали по методу ограниченного максимального правдоподобия (REML): $h^{2}=\operatorname{varA} /(\operatorname{varA}+\operatorname{varE})$, где varA - варианса аддитивных эффектов всего генотипа животного, varE варианса остаточных (неучтенных) эффектов модели.

Расчеты для дисперсионного анализа и LSM-метода проводили в программе STATISTICA 10 («StatSoft, Inc.», США). Оценку племенной ценности животных и анализ варианс осуществляли с использованием семейства программ BLUPF90 (23). Для характеристики исходных массивов данных определяли среднее арифметическое значение фенотипа по признаку в выборке $(\mu)$, ошибку среднего $\left( \pm \mathrm{m}_{\mu}\right)$, стандартное отклонение по признаку в выборке $(\sigma)$.

Результаты. Результаты детекции генотипов показаны на рисунке.

Свиноматки крупной белой породы превосходили свиней породы ландрас по исследуемым признакам на 3-7 \% (за исключением показателя $\mathrm{BW})$. Обращают на себя внимание значения фенотипических стандартных 
отклонений, характеризующие анализируемые породные популяции как перспективные в отношении повышения скорости генетического прогресса по признакам фертильности. То есть степень наблюдаемой изменчивости по признакам свидетельствует о достаточно высоком потенциале разводимого поголовья для достижения теоретически возможного эффекта от селекционных мероприятий (табл. 1). Наследуемость анализируемых признаков характеризовалась невысокой вариабельностью: 0,115-0,232 для выборки свиней крупной белой и 0,010-0,338 - для животных породы ландрас. Самые высокие значения коэффициентов наследуемости были выявлены для показателя средняя масса поросенка при рождении $\left(\mathrm{h}^{2}=0,232\right.$ для крупной белой породы, $\mathrm{h}^{2}=0,338$ для породы ландрас) благодаря снижению фенотипической изменчивости за счет учета в модели влияния фактора NBA (см. табл. 1).
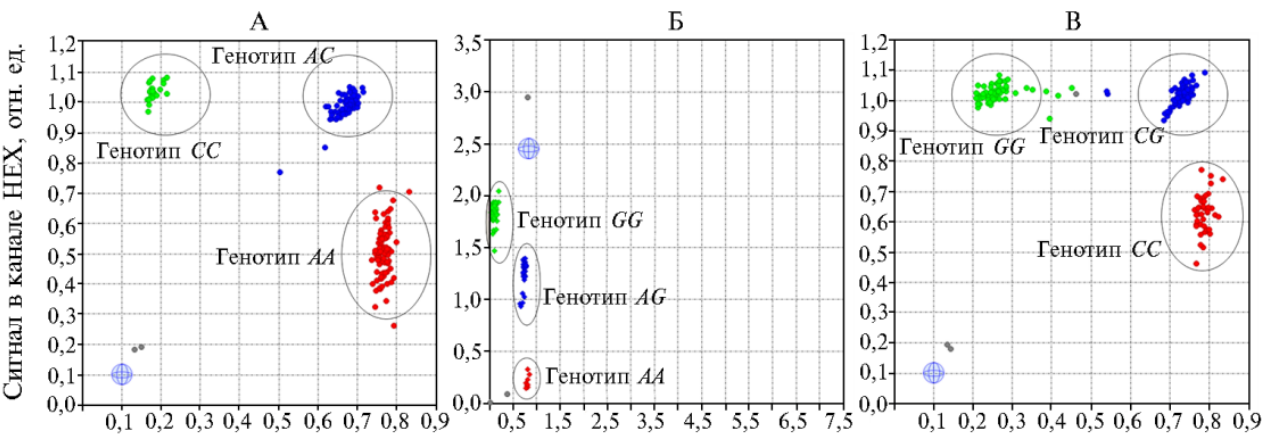

Сигнал в канале FАМ, отн. ед.

Результаты детекции свиней (Sus scrofa) пород крупная белая и ландрас по ДНК-маркерам $E S R$ (A), ECR F18/FUT1 (Б) и MUC4 (В) методом ПЦР по технологии FLASH (fluorescent amplification-based specific hybridization) с детекцией по конечной точке (Fluidigm EP1, «Fluidigm Corporation», США) (ООО «Селекционно-гибридный центр», Воронежская обл., 20172018 годы).

1. Характеристика воспроизводительных качеств в исследуемой выборке свиней (Sus scrofa) пород крупная белая и ландрас (ООО «Селекционно-гибридный центр», Воронежская обл., 2017-2018 годы)

\begin{tabular}{c|l|c|c|c|c|c}
\hline \multirow{2}{*}{ Порода } & \multirow{2}{*}{ Признак } & \multicolumn{5}{c}{ Показатели по признакам } \\
\cline { 3 - 7 } & & $n$, гол. & $n$, опоросов & $\mu \pm \mathrm{m}_{\mu}$ & $\sigma$ & $\mathrm{h}^{2}$ \\
\hline Крупная белая & TNB & 894 & 2250 & $14,6 \pm 0,1$ & 4,1 & 0,179 \\
& NBA & & & $13,5 \pm 0,1$ & 3,8 & 0,155 \\
\multirow{5}{*}{ Ландрас } & BW & & & $1,45 \pm 0,01$ & 0,22 & 0,232 \\
& WW & \multirow{2}{*}{513} & 1360 & $76,6 \pm 0,3$ & 13,5 & 0,115 \\
& TNB & & & $13,7 \pm 0,1$ & 3,5 & 0,165 \\
& NBA & & $12,6 \pm 0,1$ & 3,2 & 0,100 \\
& BW & & $1,45 \pm 0,01$ & 0,23 & 0,338 \\
& WW & & & $74,6 \pm 0,3$ & 12,6 & 0,010
\end{tabular}

$\overline{П р и ~ м ~ е ч ~ а ~ н ~ и ~ е . ~ T N B ~-~ ч и с л о ~ п о р о с я т ~ п р и ~ р о ж д е н и и ~ з а ~ о д и н ~ о п р о с, ~ N B A ~-~ ч и с л о ~ ж и в о р о ж д е н н ы х ~}$ поросят за один опорос, BW - средняя масса поросенка в гнезде при рождении, WW - молочность свиноматки (масса гнезда при отъеме на 21-е сут); $\mu$ - среднее арифметическое значение фенотипа по признаку в выборке, $\mathrm{m}_{\mu}$ - ошибка среднего, $\sigma-$ стандартное отклонение по признаку в выборке, $\mathrm{h}^{2}-\mathrm{ko-}^{2}$ эффициент наследуемости признака.

Согласно критерию $\chi^{2}$, выявили достоверные отклонения частот генотипов от состояния популяционного равновесия для животных крупной белой породы по гену $I G F 2$ ( $<<0,01)$ и породы ландрас по генам IGF2 (p < 0,01), ECR F18/FUT1 (p <0,01) и MUC4 (p <0,001) (табл. 2). Величина коэффициента гомозиготности по Робертсону $(\mathrm{Ca})$ была наибольшей для генотипов по IGF2 и ECR F18/FUT1, при этом для особей крупной белой породы этот показатель достигал соответственно 0,76 и 0,65 против 0,60 и 0,72 для породы ландрас. В то же время распределение ча- 
стот аллелей для генов IGF2 и ESR в изучаемых выборках животных кардинально различалось, что отчасти может указывать на породоспецифические особенности в проявлении фенотипа.

2. Распределение частот генотипов и аллелей по генам IGF2, ECR F18/FUT1, ESR и MUC4 у свиноматок (Sus scrofa) пород крупная белая и ландрас $\left(\mu \pm \mathrm{m}_{\mu}\right.$, ООО «Селекционно-гибридный центр», Воронежская обл., 2017-2018 годы)

\begin{tabular}{|c|c|c|c|c|c|c|c|c|}
\hline \multirow{2}{*}{ ДНК-маркер } & \multirow{2}{*}{ ЧРГ } & \multicolumn{3}{|c|}{ Генотип } & \multicolumn{2}{|c|}{ Частота аллелей } & \multirow{2}{*}{$\chi^{2}$} & \multirow{2}{*}{$\mathrm{Ca}$} \\
\hline & & 11 & 12 & 22 & 1 & 2 & & \\
\hline \multirow{3}{*}{$I G F 2$} & & & ру ун н я & 5 елая п & род а & & & \\
\hline & $\mathrm{H}$ & $0,73 \pm 0,01$ & $0,26 \pm 0,01$ & $0,01 \pm 0,00$ & $0,86 \pm 0,01$ & $0,14 \pm 0,01$ & 10,7 & 0,76 \\
\hline & $\mathrm{O}$ & 0,74 & 0,24 & 0,02 & & & & \\
\hline \multirow[t]{2}{*}{ ECR F18/FUT1 } & $\mathrm{H}$ & $0,06 \pm 0,00$ & $0,34 \pm 0,01$ & $0,60 \pm 0,01$ & $0,23 \pm 0,01$ & $0,77 \pm 0,01$ & 2,7 & 0,65 \\
\hline & $\mathrm{O}$ & 0,05 & 0,35 & 0,60 & & & & \\
\hline \multirow[t]{2}{*}{$E S R$} & $\mathrm{H}$ & $0,06 \pm 0,00$ & $0,36 \pm 0,01$ & $0,58 \pm 0,01$ & $0,24 \pm 0,01$ & $0,76 \pm 0,01$ & 0,0 & 0,64 \\
\hline & $\mathrm{O}$ & 0,06 & 0,36 & 0,58 & & & & \\
\hline \multirow[t]{2}{*}{$M U C 4$} & $\mathrm{H}$ & $0,39 \pm 0,01$ & $0,46 \pm 0,01$ & $0,15 \pm 0,01$ & $0,62 \pm 0,01$ & $0,38 \pm 0,01$ & 1,1 & 0,53 \\
\hline & $\mathrm{O}$ & 0,39 & 0,47 & 0,14 & & & & \\
\hline \multirow{3}{*}{$I G F 2$} & & & & н д р а с & & & & \\
\hline & $\mathrm{H}$ & $0,06 \pm 0,01$ & $0,44 \pm 0,01$ & $0,50 \pm 0,01$ & $0,28 \pm 0,01$ & $0,72 \pm 0,01$ & 7,6 & 0,60 \\
\hline & $\mathrm{O}$ & 0,08 & 0,40 & 0,52 & & & & \\
\hline \multirow[t]{2}{*}{ ECR F18/FUT1 } & $\mathrm{H}$ & $0,02 \pm 0,00$ & $0,30 \pm 0,01$ & $0,68 \pm 0,01$ & $0,17 \pm 0,01$ & $0,73 \pm 0,01$ & 8,3 & 0,72 \\
\hline & $\mathrm{O}$ & 0,03 & 0,28 & 0,69 & & & & \\
\hline \multirow[t]{2}{*}{$E S R$} & $\mathrm{H}$ & $0,56 \pm 0,01$ & $0,36 \pm 0,01$ & $0,08 \pm 0,01$ & $0,74 \pm 0,01$ & $0,26 \pm 0,01$ & 3,6 & 0,62 \\
\hline & $\mathrm{O}$ & 0,55 & 0,38 & 0,07 & & & & \\
\hline \multirow[t]{2}{*}{ MUC4 } & $\mathrm{H}$ & $0,38 \pm 0,01$ & $0,53 \pm 0,01$ & $0,09 \pm 0,01$ & $0,64 \pm 0,01$ & $0,36 \pm 0,01$ & 28,7 & 0,54 \\
\hline & $\mathrm{O}$ & 0,41 & 0,46 & 0,13 & & & & \\
\hline
\end{tabular}

$\overline{П ~ р ~ и ~ м ~ е ~ ч ~ а ~ н ~ и ~ е . ~ Ч Р Г ~-~ ч а с т о т а ~ р а с п р е д е л е н и я ~ п о ~ г е н о т и п а м, ~} \mathrm{H}$ - наблюдаемая, $\mathrm{O}-$ ожидаемая. Аллели 1,2 и генотипы $11,12,22$ соответствуют аллелям $A, G$ и генотипам $A A, A G, G G$ для $I G F 2$ и $E C R$ $F 18 / F U T 1$; аллелям $A, C$ и генотипам $A A, A C, C C$ - для $E S R$; аллелям $C, G$ и генотипам $C C, C G, G G-$ для MUC4.

Анализ показателей значимости генетических факторов ( $F$-критерий) для каждого анализируемого маркера позволил выявить маркерные генотипы, которые оказывают достоверное влияние на фенотипические проявления признаков воспроизводства и на изменчивость EBV (табл. 3).

3. Значимость влияния генотипа свиноматок (Sus scrofa) пород крупная белая и ландрас по исследуемым генетическим маркерам на изменчивость фенотипических и генетических показателей воспроизводства (OOO «Селекционногибридный центр», Воронежская обл., 2017-2018 годы)

\begin{tabular}{|c|c|c|c|c|c|c|c|c|}
\hline \multirow{3}{*}{ Показатель } & \multicolumn{8}{|c|}{$F$-критерий фактора } \\
\hline & \multicolumn{4}{|c|}{ крупная белая порода $(n=894)$} & \multicolumn{4}{|c|}{ ландрас $(n=513)$} \\
\hline & $I G F 2$ & ECR F18 & $E S R$ & $M U C 4$ & $I G F 2$ & $E C R F 18$ & $E S R$ & $M U C 4$ \\
\hline $\mathrm{PHE}_{\mathrm{TNB}}$ & 0,24 & $5,79^{*}$ & $6,27 *$ & 0,43 & 1,78 & 3,08 & 0,54 & 0,49 \\
\hline PHE $_{\text {NBA }}$ & 0,16 & $10,79 *$ & $6,80^{*}$ & 0,23 & 0,78 & 1,24 & 1,85 & 0,46 \\
\hline $\mathrm{PHE}_{\mathrm{BW}}$ & 1,13 & $4,28 *$ & 2,62 & $8,75^{*}$ & 0,72 & 2,10 & 2,00 & $3,21 *$ \\
\hline PHE $_{\text {BWadi }}$ & 1,44 & 2,79 & 1,20 & $12,59 *$ & 1,51 & 2,63 & 2,44 & $4,75^{*}$ \\
\hline PHEWW & 1,18 & 0,21 & 1,84 & 0,36 & $6,01^{*}$ & 0,21 & 0,68 & 1,47 \\
\hline PHE $_{W W a d i}$ & 0,30 & 0,30 & 1,80 & 1,00 & $5,31^{*}$ & 1,14 & 0,10 & 0,30 \\
\hline $\mathrm{EBV}_{\mathrm{TNB}}$ & 1,04 & 2,95 & $5,30^{*}$ & $3,70^{*}$ & 1,65 & 3,01 & 0,87 & 0,44 \\
\hline $\mathrm{EBV}_{\mathrm{NBA}}$ & 0,02 & $8,96^{*}$ & $7,90^{*}$ & $4,93^{*}$ & 0,85 & 0,47 & $4,51^{*}$ & 0,02 \\
\hline $\mathrm{EBV}_{\mathrm{BW}}$ & 1,44 & $3,46^{*}$ & $10,90^{*}$ & $22,84^{*}$ & 1,00 & 2,80 & $10,69^{*}$ & $3,19 *$ \\
\hline $\mathrm{EBV}_{\mathrm{WW}}$ & 2,05 & $3,58^{*}$ & 0,32 & 2,43 & $14,99^{*}$ & 2,86 & 2,30 & 2,76 \\
\hline
\end{tabular}

П р и м е ч а н и е. РНЕ - фенотипический показатель, EBV - оценка племенной ценности для признаков; TNB - число поросят при рождении за один опрос, NBA - число живорожденных поросят за один опорос, BW - средняя масса поросенка в гнезде при рождении, BW $\mathrm{Bdj}_{-}$средняя скорректированная масса поросенка в гнезде при рождении, WW - молочность свиноматки (масса гнезда при отъеме на 21-е сут), $\mathrm{WW}_{\mathrm{adj}}$ - скорректированная молочность свиноматки (масса гнезда при отъеме на 21-е сут).

* Значение $F$-критерия достоверно при р $<0,05$ для соответствующего числа степеней свободы.

Были получены достоверные значения по критерию Фишера для маркера IGF2 при исследовании фенотипических и генетических показателей молочности свиноматок (PHEww, PHEWwadj, EBV $\left.\mathrm{Ww}_{\mathrm{W}}\right)$ породы ландрас. С нашей точки зрения, выявленная взаимосвязь может объясняться лучшими характеристиками молочной продуктивности свиноматок, обла- 
дающих предпочтительным генотипом по этому маркеру (табл. 4). В проведенных ранее исследованиях (22) установлено, что особи, несущие в своем генотипе аллели $A$ по $I G F 2$, характеризовались наименьшими значениями толщины шпика и выделялись более высокой скороспелостью. В то же время свиноматки с таким генотипом превосходили гетерозиготных и гомозиготных по альтернативному аллелю животных по показателю молочности. Стоит отметить, что показатель «молочность свиноматки», измеряемый как масса гнезда поросят в возрасте 21 сут, мог быть обусловлен скоростью роста поросят, то есть животные, несущие в своем генотипе желательные аллели по маркеру, имели бо́льшую скорость роста, позволившую им набрать бо́льшую массу к моменту отъема. Для крупной белой породы значимых различий по этому маркеру мы не выявили.

4. Средние значения фенотипов свиноматок (Sus scrofa) пород крупная белая и ландрас по исследуемым признакам в зависимости от генотипа по маркерам ( $\mu \pm \mathrm{m}_{\mu}$, ООО «Селекционно-гибридный центр», Воронежская обл., 2017 2018 годы)

\begin{tabular}{|c|c|c|c|c|c|c|c|c|}
\hline \multirow{2}{*}{$\begin{array}{l}\text { Генотип } \\
\text { по маркеру }\end{array}$} & & \multirow{2}{*}{$\begin{array}{l}n, \text { опо- } \\
\text { росы }\end{array}$} & \multicolumn{6}{|c|}{ Средние значения фенотипических показателей (LS) по признаку } \\
\hline & & & TNB & NBA & BW & $\mathrm{BW}_{\mathrm{adj}}$ & WW & $\mathrm{WW}_{\mathrm{adj}}$ \\
\hline \multicolumn{9}{|c|}{ К рупная бе лая по рода $(n=2250$ опоросов $)$} \\
\hline \multirow[t]{3}{*}{ IGF2 } & $A A$ & 1649 & $14,9 \pm 0,2$ & $13,6 \pm 0,1$ & $1,47 \pm 0,01$ & $1,46 \pm 0,01$ & $76,8 \pm 0,5$ & $60,2 \pm 0,1$ \\
\hline & $A G$ & 576 & $14,8 \pm 0,2$ & $13,7 \pm 0,2$ & $1,47 \pm 0,01$ & $1,46 \pm 0,01$ & $76,4 \pm 0,7$ & $60,2 \pm 0,1$ \\
\hline & $G G$ & 25 & $15,2 \pm 0,8$ & $13,7 \pm 0,8$ & $1,40 \pm 0,05$ & $1,39 \pm 0,04$ & $73,2 \pm 2,6$ & $59,9 \pm 0,4$ \\
\hline \multirow[t]{3}{*}{ ECR F18/FUT1 } & $A A$ & 128 & $13,8 \pm 0,4^{*}$ & $12,2 \pm 0,3^{*}$ & $1,50 \pm 0,02^{*}$ & $1,45 \pm 0,02$ & $76,5 \pm 1,2$ & $60,3 \pm 0,2$ \\
\hline & $A G$ & 759 & $15,0 \pm 0,2$ & $13,7 \pm 0,2$ & $1,45 \pm 0,01$ & $1,44 \pm 0,01$ & $76,8 \pm 0,6$ & $60,2 \pm 0,1$ \\
\hline & $G G$ & 1363 & $15,0 \pm 0,2$ & $13,8 \pm 0,2$ & $1,47 \pm 0,01$ & $1,47 \pm 0,01$ & $76,5 \pm 0,5$ & $60,2 \pm 0,1$ \\
\hline \multirow[t]{3}{*}{ ESR } & $A A$ & 129 & $14,7 \pm 0,4$ & $13,4 \pm 0,3$ & $1,44 \pm 0,02$ & $1,42 \pm 0,01$ & $75,0 \pm 1,2$ & $60,3 \pm 0,2$ \\
\hline & $A C$ & 817 & $14,6 \pm 0,2$ & 13 & $1,48 \pm 0$ & 1,46 & $77,1 \pm 0,6$ & 0,1 \\
\hline & $C C$ & 1304 & $15,2 \pm 0,2^{*}$ & $13,9 \pm 0,2^{*}$ & $1,45 \pm 0,01$ & $1,45 \pm 0,01$ & $76,6 \pm 0,5$ & 0,1 \\
\hline \multirow[t]{3}{*}{ MUC4 } & $C C$ & 884 & $14,9 \pm 0,2$ & & $1,49 \pm 0$ & $1,48 \pm 0$ & $75,9 \pm 0,6$ & $=0,1$ \\
\hline & $C G$ & 1034 & $14,7 \pm 0,2$ & $, 5 \pm 0,2$ & $1,46 \pm 0$ & $1,44 \pm 0$ & $76,3 \pm 0,6$ & $3 \pm 0,1$ \\
\hline & $G G$ & 332 & $15,0 \pm 0,3$ & $13,6 \pm 0,3$ & $1,43 \pm 0,01^{*}$ & $1,41 \pm 0,01^{*}$ & $76,6 \pm 0,8$ & $60,1 \pm 0,1$ \\
\hline & & & Л а н & $n a r=$ & 360 опоросо & & & \\
\hline \multirow[t]{3}{*}{$I G F 2$} & $A A$ & 87 & $14,0 \pm 0,4$ & $13,0 \pm 0,4$ & $1,51 \pm$ & 1,51 & $79,5 \pm 1,5^{*}$ & $\pm 0,3^{*}$ \\
\hline & $A G$ & 591 & $14,0 \pm 0,2$ & & & & $\pm 0,7$ & \\
\hline & $G G$ & 682 & $13,6 \pm 0,1$ & & $1,47 \pm 0$ & $1,46 \pm 0$ & $74,1 \pm 0,7$ & 0,1 \\
\hline \multirow[t]{3}{*}{ ECR F18/FUT1 } & $A A$ & 23 & $14,3 \pm 0,8$ & $13,0 \pm 0,7$ & $1,46 \pm 0,05$ & $1,46 \pm 0,04$ & $73,6 \pm 2,7$ & $61,0 \pm 0,6$ \\
\hline & $A G$ & 407 & $14,2 \pm 0,2$ & $12,9 \pm 0,2$ & $1,44 \pm 0,01$ & $1,44 \pm 0,01$ & $75,1 \pm 0,8$ & $61,7 \pm 0,2$ \\
\hline & $G G$ & 930 & $13,7 \pm 0,2$ & $12,6 \pm 0,2$ & $1,48 \pm 0,01$ & $1,47 \pm 0,01$ & $75,3 \pm 0,6$ & $61,7 \pm 0,1$ \\
\hline \multirow[t]{3}{*}{ ESR } & $A A$ & 759 & $13,8 \pm 0,2$ & $=0,2$ & $1,46 \pm 0,01$ & $1,45 \pm$ & $75,1 \pm 0,7$ & \\
\hline & $A C$ & 496 & $14,0 \pm 0,2$ & $12,9 \pm 0,2$ & $1,48 \pm 0,01$ & $1,47 \pm 0,01$ & $75,6 \pm 0,7$ & $61,7 \pm 0,2$ \\
\hline & $C C$ & 105 & $13,9 \pm 0,4$ & $12,9 \pm 0,3$ & $1,51 \pm 0,02$ & $1,51 \pm 0,02$ & $74,0 \pm 1,3$ & $61,7 \pm 0,3$ \\
\hline \multirow[t]{3}{*}{$M U C 4$} & $C C$ & 517 & $13,8 \pm 0,2$ & $12,7 \pm 0,2$ & $1,49 \pm 0,01$ & $1,48 \pm 0,01$ & $74,4 \pm 0,8$ & $61,7 \pm 0,2$ \\
\hline & $C G$ & 715 & $13,9 \pm 0,2$ & $12,8 \pm 0,2$ & $1,47 \pm 0,01$ & $1,46 \pm 0,01$ & $75,7 \pm 0,7$ & $61,8 \pm 0,1$ \\
\hline & $G G$ & 128 & $13,6 \pm 0,3$ & $12,5 \pm 0,3$ & $1,43 \pm 0,02^{*}$ & $1,42 \pm 0,02 *$ & $75,0 \pm 1,2$ & $61,6 \pm 0,2$ \\
\hline \multicolumn{9}{|c|}{$\begin{array}{l}\text { П р и м е ч а н и е. TNB - число поросят при рождении за один опорос, NBA - число живорожденных } \\
\text { поросят за один опорос, BW - средняя масса поросенка в гнезде при рождении, } \text { BW }_{\text {adj }}-\text { средняя скор- } \\
\text { ректированная масса поросенка в гнезде при рождении, WW - молочность свиноматки (масса гнезда } \\
\text { при отъеме на } 21 \text {-е сут), } W_{\text {adj }}-\text { скорректированная молочность свиноматки (масса гнезда при отъ- } \\
\text { еме на } 21 \text {-е сут). } \\
\text { * Различия по отношению к группе с альтернативным гомозиготным генотипом статистически значимы } \\
\text { при р }<0,05 \text {. }\end{array}$} \\
\hline
\end{tabular}

Установлено достоверное влияние генотипа животных крупной белой породы по маркеру ECR F18/FUT1 на фенотип по признакам «число рожденных поросят», «средняя масса поросенка при рождении», а также «число живорожденных поросят в гнезде при рождении». Влияние ДНКмаркера на генетическую ценность особей подтверждалось для показателей многоплодия и средней массы поросенка при рождении. Так, свиноматки с генотипом $A A$ по $E C R$ F18/FUT1 характеризовались достоверно меньшим числом рожденных поросят за один опорос (на 8,0-8,5 \%), однако средняя масса этих поросят достоверно (p < 0,05) превосходила аналогичный показатель в других группах (на 2,0-3,0 \%). По средним значениям оценок генетической ценности свиноматки с генотипом $A A$ по признакам 
многоплодия (TNB и NBA) достоверно уступали гетерозиготным и гомозиготным по альтернативному аллелю животным $\left(\bar{X}_{\mathrm{EBV}(\mathrm{AA})}=-0,50\right.$ и $\left.-0,55\right)$. Для группы свиней породы ландрас выявленная закономерность не нашла подтверждения, достоверных различий между особями с разными генотипами по анализируемым признакам мы не обнаружили.

Неоднозначные результаты были получены при исследовании влияния маркера $E S R$ на признаки воспроизводства. Для животных крупной белой породы выявили достоверное $(\mathrm{p}<0,05)$ влияние генотипа по этому маркеру на фенотипические показатели количества поросят при рождении (TNB и NBA) и на значения EBV для признака «средняя масса поросят при рождении». При этом свиноматки с генотипом $C C$ отличались от остальных лучшими характеристиками (фенотипическими и генетическими). Влияние маркера $E S R$ на фенотип свиней породы ландрас по показателям воспроизводства мы не установили, однако средние значения EBV по числу всех и живорожденных поросят_оказались достоверно выше у животных с гетерозиготным генотипом: $\bar{X}_{\mathrm{EBV}(\mathrm{AC})}=+0,10$, при том что $\bar{X}_{\mathrm{EBV}(\mathrm{CC})}=0,00$ и $\bar{X}_{\mathrm{EBV}(\mathrm{AA})}=-0,10$. По признаку «средняя масса поросенка при рождении» лучшими показателями характеризовались свиноматки обеих пород с генотипом $C C$.

Генотипы свиней по маркеру MUC4 оказались значимыми факторами для проявления изменчивости по признаку «средняя масса поросят при рождении» для животных обеих пород, причем достоверное влияние генотипов было обнаружено и для фенотипических (абсолютных и скорректированных), и для генетических оценок особей $(\mathrm{p}<0,05)$. Свиноматки с генотипами $C C$ и $C G$ превосходили гомозиготных по аллелю $G$ особей по абсолютному и скорректированному фенотипическому показателю массы поросенка при рождении (на 2,0-5,0 \% для породы крупная белая и на 4,0-4,5 \% для породы ландрас). Значения EBV свиноматок с генотипом $C C$ в среднем были достоверно выше по сравнению с гетерозиготными животными и особями с генотипом $G G$ : $X_{\mathrm{EBV}(\mathrm{CC})}=+0,01$ для породы крупная белая, $\bar{X}_{\mathrm{EBV}(\mathrm{CC})}=0,00$ для породы ландрас при отрицательных значениях в сравниваемых группах.

Проведенные нами ранее исследования не показали влияния полиморфизма по IGF2 на воспроизводительные качества свиней крупной белой породы, а генотип $C C$ по $E S R$ был положительно связан с мясными и откормочными качествами (24). В ряде работ, посвященных поиску связи генетических вариантов по $E S R$ с признаками продуктивности, продемонстрировано превосходство носителей аллеля $C$ крупной белой породы по репродуктивным признакам $(25,26)$, что подтверждается и нашими данными.

Полиморфизм ECR F18/FUT1 ассоциирован с устойчивостью к колибактериозу. Р. Horak с соавт. (27), исследовав этот полиморфизм, сообщили о значительно меньшем многоплодии и снижении общего числа поросят в гнезде у свиноматок с генотипом $A A$ в популяции свиней чернопестрой породы. В свою очередь, W.B. Вао с соавт. $(28,29)$ обнаружили, что по показателю размера гнезда при рождении носители генотипа $A A$ у свиней породы дюрок и сутай превосходили носителей $A G$ и $G G$ генотипов. В наших исследованиях было показано превосходство носителей $A A$ по общему числу рожденных и числу живорожденных поросят в опоросе, что согласуется с результатами, полученными W.B. Вао и коллегами. L. Fontanesi с соавт. (30), изучая полиморфизм в гене $M U C 4$, обнаружили, что аллель $G$, связанный с восприимчивостью к ETEC (enterotoxigenic Escherichia coli K88), обусловливает более высокую скороспелость свиней 
пород крупная белая ( $\mathrm{P}=6,66 \mathrm{E}-04)$ и ландрас $(\mathrm{P}=7,23 \mathrm{E}-12)$, что свидетельствует об антагонистической ассоциации аллелей $M U C 4$ g.8227C $>\mathrm{G}$ по восприимчивости к ЕТЕС и характеристикам роста. А. Банникова (31) обнаружила превосходство свиней крупной белой породы с $C C$ генотипом по многоплодию, однако в наших исследованиях значимой зависимости по этому признаку у свиней обеих пород выявлено не было.

Таким образом, нами подтверждено влияние некоторых генотипов по генетическим маркерам IGF2, ECR F18/FUT1, ESR, MUC4 на изменчивость фенотипических показателей воспроизводительных качеств свиней и характеристики их племенной ценности. Наилучшими показателями по признакам многоплодия выделялись животные с генотипами $A G$ и $G G$ по маркеру $E C R$ F18/FUT1 и CC по ESR (для крупной белой породы); наиболее высокие показатели средней массы поросят при рождении отмечены у свиноматок с генотипами $C C$ и $C G$ по маркеру $M U C 4$ (для обеих пород); лучшие значения по молочности выявлены у особей с генотипом $A A$ по IGF2 (для породы ландрас). Однако важно отметить, что для признаков фертильности животных характерна наиболее высокая обусловленность паратипическими факторами (более 90 \%), а также аддитивными эффектами значительного количества генов и их комбинаций, влияющих (как положительно, так и отрицательно) на биологические механизмы функции воспроизведения, каждый из которых может оказаться доминирующим при получении итогового результата. Кроме того, воспроизводительные качества свиней характеризуются наличием генетических взаимосвязей, в том числе отрицательных. Например, для пары признаков «число живорожденных поросят за один опорос» и «средняя масса поросенка в гнезде при рождении» $r_{g}=-0,33$. Это существенно осложняет оценку влияния генетических маркеров на проявление исследуемых признаков и отбор животных при организации воспроизводства, поскольку особи, несущие в своем генотипе желательные аллели по одному маркеру, не всегда будут характеризоваться наличием желательных аллелей по другому.

Итак, в целом полученные результаты позволяют рекомендовать использование подходов маркерной селекции наряду с традиционными методами оценки генетического потенциала свиней (BLUP AM) по признакам фертильности на этапе принятия решения об отборе особи в селекционную группу или при выбраковке как маточного поголовья, так и хряков-производителей. При подборе родительских генотипов данные о генетической особенностях животных по маркерам IGF2, ECR F18/FUT1, $E S R, M U C 4$ дадут возможность повысить частоту встречаемости желательных аллелей и генотипов, что позволит увеличить скорость генетического совершенствования популяций свиней пород крупная белая и ландрас по показателям фертильности.

\section{ЛИТЕРАТУРА}

1. Torres Filho R.A., Torres R.A., Lopes P.S., Pereira C.S., Euclydes R.F., Araъjo C.V., Silva M.A. Genetic trends in the performance and reproductive traits of pigs. Genetics and Molecular Biology, 2005, 28(1): 97-102 (doi: 10.1590/S1415-47572005000100017).

2. Radojkovic D., Petrovic M., Radovic C., Parunovic N., Popovac M., Gogic M. Heritability and correlation of litter traits in pigs determined by REML method. Biotechnology in Animal Husbandry, 2012, 28(4): 771-778 (doi: 10.2298/BAH1204771R).

3. Мельникова Е.Е., Сермягин А.А., Харитонов С.Н., Контэ А.Ф., Требунских Е.А., Зиновьева Н.А. Выбор селекционных критериев для определения комплексной племенной ценности свиней крупной белой породы. Свиноводство, 2019, 1: 13-17.

4. Ye J., Tan C., Hu X., Wang A., Wu Z. Genetic parameters for reproductive traits at different 
parities in Large White pigs. Journal of Animal Science, 2018, 96(4): 1215-1220 (doi: 10.1093/jas/sky066).

5. Spötter A., Distl O. Genetic approaches to the improvement of fertility traits in the pig. The Veterinary Journal, 2006, 172(2): 234-247 (doi: 10.1016/j.tvjl.2005.11.013).

6. Wakchaure R., Ganguly S., Praveen P.K., Kumar A., Sharma S., Mahajan T. Marker assisted selection (MAS) in animal breeding: a review. J. Drug. Metab. Toxicol., 2015, 6: e127 (doi: 10.4172/2157-7609.1000e127).

7. Rothschild M., Jacobson C., Vaske D., Tuggle C., Wang L., Short T., Eckardt G., Sasaki S., Vincent A., McLaren D., Southwood O., van der Steen H., Mileham A., Plastow G. The estrogen receptor locus is associated with a major gene influencing litter size in pigs. Proceedings of the National Academy of Sciences, 1996, 93(1): 201-205 (doi: 10.1073/pnas.93.1.201).

8. Wu Z.F., Liu D.W., Wang Q.L., Zeng H.Y., Chen Y.S., Zhang H. Study on the association between estrogen receptor gene (ESR) and reproduction traits in landrace pigs. Acta Genetica Sinica, 2006, 33(8): 711-716 (doi: 10.1016/S0379-4172(06)60103-0).

9. Goliášová E., Dvořák J. The oestrogen receptor gene (ESR) PvuII polymorphism allele frequencies in Czech Large White and Landrace. Acta univ. agric. et silvic. Mendel. Brun., 2005, LIII(2): 33-38.

10. Omelka R., Bauerova M., Mlynek J., Buchova B., Peskovicova D., Bulla J. Effect of the estrogen receptor (ESR) gene on reproductive traits of Large White, White Meaty and Landrace pigs. Czech J. Anim. Sci., 2005, 50(6): 249-253 (doi: 10.17221/4165-CJAS).

11. Костюнина О.В., Свеженцева Н.А., Зиновьева Н.А., Шахин А.В., Доцев А.В., Сизарева Е.И., Шавырина К.М., Гладырь Е.А., Эрнст Л.К. Племенная ценность хряков крупной белой породы с различными генотипами по ДНК-маркеру ESR. Достижения науки и техники АПК, 2011, 10: 57-58.

12. Гиниятуллин И.И., Рахматов Л.А., Ахметов Т.М., Муллахметов Р.Р., Тюлькин С.В. Молекулярная диагностика полиморфизма генов ESR и PRLR, влияющих на репродуктивные качества свиней. Ученые записки Казанской государственной академии ветеринарной медицины им. Н.Э. Баумана, 2016, 1: 107-109.

13. Колосов А.Ю., Широкова Н.В., Максимов Г.В., Леонова М.А., Радюк А.В. Оценка силы статистического влияния полиморфизма гена ESR1 на воспроизводительные признаки свиней. Аграрный вестник Урала, 2016, 2(144): 17-19.

14. Wang S.J., Liu W.J., Yang L.G. Sargent C.A., Liu H.B., Wang C., Liu X.D., Zhao S.H., Affara N.A., Liang A.X., Zhang S.J. Effects of FUT1 gene mutation on resistance to infectious disease. Mol. Biol. Rep., 2012, 39(3): 2805-2810 (doi: 10.1007/s11033-011-1039-0).

15. Zhu S., Liu Y., Dong W., Zheng X., Zhu G., Wu S., Bao W. Polymorphism of FUT1 gene M307 and its relationship with partial immune indexes and economic traits in Yorkshire pigs. Asian Journal of Animal and Veterinary Advances, 2014, 9(4): 253-261 (doi: 10.3923/ajava.2014.253.261).

16. Гетманцева Л.В., Михайлов Н.В., Колосов А.Ю., Радюк А.В. Полиморфизм гена MUC4 и воспроизводительные качества свиней. Известия НВ АУК, 2013, 3(31): 1-3.

17. Jørgensen C.B., Cirera S., Archibald A. L., Anderson L., Fredholm M., Edfors-Lilja I. Porcine polymorphisms and methods for detecting them. International application published under the patent cooperation treaty (PCT). PCT/DK2003/000807 or WO2004/048606-A2. 2004.

18. Balcells I., Castelló A., Mercadé A., Noguera J.L., Fernández-Rodríguez A., Sànchez A., Tomàs A. Analysis of porcine MUC4 gene as a candidate gene for prolificacy QTL on SSC13 in an Iberian $\times$ Meishan $F_{2}$ population. BMC Genetics, 2011, 31(12): 93 (doi: 10.1186/1471-2156-12-93).

19. Van Laere A.S., Nguyen M., Braunschweig M., Nezer C., Collette C., Moreau L., Archibald A.L., Haley C.S., Buys N., Tally M., Andersson G., Georges M., Andersson L. A regulatory mutation in IGF2 causes a major QTL effect on muscle growth in the pig. Nature, 2003, V(425): 832-836 (doi: 10.1038/nature02064).

20. Костюнина О.В., Крамаренко С.С., Свеженцева Н.А., Сизарева Е.И., Зиновьева Н.А. Ассоциация гена IGF2 с продуктивными качествами свиней (Sus scrofa) крупной белой породы с учетом половой дифференциации. Сельскохозяйственная биология, 2015, 50(6): 736-745 (doi: 10.15389/agrobiology.2015.6.736rus).

21. Карпушкина Т.В., Костюнина О.В., Сизарева Е.И., Зиновьева Н.А. Продуктивные качества свиней крупной белой породы в зависимости от генотипа по IGF2 и CTSD. Достижения науки и техники АПК, 2016, 30(6): 82-85.

22. Мельникова Е.Е., Бардуков Н.В., Форнара М.С., Костюнина О.В., Сермягин А.А., Зайцев А.М., Зиновьева Н.А. Влияние генотипов по IGF2, CCKAR и $M C 4 R$ на фенотипические показатели и племенную ценность свиней по хозяйственно полезным признакам. Сельскохозяйственная биология, 2018, 53(4): $723-734$ (doi: 10.15389/agrobiology.2018.4.723rus).

23. Misztal I., Tsuruta S., Strabel T., Auvray B., Druet T., Lee D.H. BLUPF90 and related programs (BGF90). Proc. 7th World Congress on genetics applied to livestock production. Montpellier, Communication, 2002, 28-27, 28: 21-22.

24. Костюнина О.В., Свеженцева Н.А., Зиновьева Н.А., Доцев А.В., Шахин А.В., Сизарева Е.И., Гладырь Е.А. Влияние маркерного генотипа по $E S R$ и IGF2 на племенную ценность хряков крупной белой породы. Сельскохозяйственная биология, 2011, 6: 54-59. 
25. Horogh G., Zsolnai A., Komiósi I., Nyíri A., Anton I., Fésüs L. Oestrogen receptor genotypes and litter size in Hungarian Large White pigs. Journal of Animal Breeding and Genetics, 2005, 122(1): 56-61 (doi: 10.1111/j.1439-0388.2004.00483.x).

26. Полозюк О.Н. Теоретическое обоснование и практическое использование ДНК-генотипирования в селекции свиней. Автореф. докт. дис. Ставрополь, 2013.

27. Horák P., Urban T., Dvoŕák J. The FUT1 and ESR genes - their variability and associations with reproduction in Přeštice Black-Pied sows. Journal of Animal Breeding and Genetics, 2005, 122(3): 210-213 (doi: 10.1111/j.1439-0388.2005.00502.x).

28. Bao W.B., Wu S.L., Cao J.J., Huang X.G., Chen G.H. Polymorphism of FUT1 gene and its relationship with litter size in Duroc pigs. Chin. J. Anim. Sci., 2009, 3: 5-7.

29. Bao W.B., Ye L., Pan Z.Y., Zhu J., Zhu G.Q., Huang X.G., Wu S.L. Beneficial genotype of swine FUT1 gene governing resistance to E. coli F18 is associated with important economic traits. Journal of Genetics, 2011, 90(2): 315-318 (doi: 10.1007/s12041-011-0059-9).

30. Fontanesi L., Bertolini F., Dall'Olio S., Buttazzoni L., Gallo M., Russo V. Analysis of association between the MUC4 g.8227C $>\mathrm{G}$ polymorphism and production traits in Italian heavy pigs using a selective genotyping approach. Animal Biotechnology, 2012, 23(3): 147-155 (doi: 10.1080/10495398.2011.653462).

31. Банникова А.Д. Полиморфизм ДНК-маркеров, ассоциированных с воспроизводительными качествами, у свиней пород крупная белая и йоркшир. Канд. дис. Дубровицы, 2012.

\title{
ФГБНУ ФНЦ животноводства - \\ ВИЖ им. академика Л.К. Эрнста,
}

142132 Россия, Московская обл., г.о. Подольск, пос. Дубровицы, 60,

Поступила в редакиию 25 декабря 2018 года

e-mail: melnikovaee@vij.ru $₫$, bardukv-nikolajj@mail.ru,

margaretfornara@gmail.ru, kostolan@yandex.ru, alex_sermyagin85@mail.ru,

gottfried.brem@agrobiogen.de,n_zinovieva@mail.ru

Sel'skokhozyaistvennaya biologiya [Agricultural Biology], 2019, V. 54, № 2, pp. 227-238

\section{THE STUDY OF EFFECT OF GENOTYPES FOR DNA MARKER ON REPRODUCTIVE QUALITIES OF SOWS OF LARGE WHITE AND LANDRACE BREEDS}

\author{
E.E. Melnikova, N.V. Bardukov, M.S. Fornara, O.V. Kostyunina, A.A. Sermyagin, \\ G. Brem, N.A. Zinovieva
}

Ernst Federal Science Center for Animal Husbandry, 60, pos. Dubrovitsy, Podolsk District, Moscow Province, 142132 Russia, e-mail melnikovaee@vij.ru ( $₫$ corresponding author), bardukv-nikolajj@mail.ru, margaretfornara@gmail.ru, kostolan@yandex.ru, alex_sermyagin85@mail.ru,gottfried.brem@agrobiogen.de,n_zinovieva@mail.ru ORCID:

Melnikova E.E. orcid.org/0000-0002-7498-1871

Bardukov N.V. orcid.org/0000-0002-5497-2409

Fornara M.S. orcid.org/0000-0002-8844-177X

Kostyunina O.V. orcid.org/0000-0001-8206-3221

Sermyagin A.A. orcid.org/0000-0002-1799-6014

Brem G. orcid.org/0000-0002-7522-0708

Zinovieva N.A. orcid.org/0000-0003-4017-6863

The authors declare no conflict of interests

Acknowledgements:

The equipment of the Center for Biological Resources and Bioengineering of Farm Animals (Ernst Federal Science Center for Animal Husbandry) was used to conduct the study.

The studies were performed with the support of the Ministry of Education and Science of the Russian Federation, a unique project number RFMEFI60417X0182.

Received December 25, 2018

doi: 10.15389 /agrobiology.2019.2.227eng

\section{Abstract}

The genetic progress by low-inherited reproduction traits in pigs can be increased by integrating into breeding programs the DNA markers, which are associated with quantitative trait loci (QTL) of reproductive qualities (marker selection, MAS). The aim of the present study was to assess the effect of DNA markers IGF2 (insulin-like growth factor 2), ECR F18/FUT1 (Escherichia coli F18 receptor), ESR (estrogen receptor) and MUC4 (mucin 4) on the fertility traits of Large White and Landrace sows. The studied traits included the total number of piglets born per litter (TNB); number of piglets born alive per litter (NBA); average birth weight (BW) and adjusted birth weight $\left(\mathrm{BW}_{\mathrm{adj}}\right.$ ); weight at weaning at 21 days $(\mathrm{WW})$ and adjusted weight at weaning at 21 days $\left(\mathrm{WW}_{\mathrm{adj}}\right)$. The genotypes frequencies of the analyzed markers were determined. Besides we identified significant deviations of the genotype frequencies from the population equilibrium for Large White breed by the IGF2 gene $(\mathrm{p}<0.01)$ and Landrace breed by the IGF2 $(\mathrm{p}<0.01)$, ECR F18/FUT1 $(\mathrm{p}<0.01)$ and MUC4 $(\mathrm{p}<0.001)$. The homozygosity coefficient according to Robertson $(\mathrm{Ca})$ was the highest for genotypes for IGF2 and ECR F18/FUT1. The values of this parameters reached 0.76 and 0.65 for Large White 
breed against 0.60 and 0.72 for Landrace breed, respectively. We calculated the heritability coefficients for the analyzed traits, which were $0.165-0.179$ for TNB, $0.100-0.155$ for NBA, $0.232-0.338$ for $\mathrm{BW}$, and $0.010-0.115$ for WW. Based on the developed equations, breeding values of pigs were determined using the BLUP AM method. The IGF2 marker showed a significant effect on the weight at weaning for Landrace sows ( $\mathrm{PHE}_{\mathrm{WW}}, \mathrm{PHE}_{\mathrm{WWadj}}, \mathrm{EBV}_{\mathrm{WW}}$ ); individuals with genotypes $A A$ and $A G$ were the best. The genotype for $E C R$ F18/FUT1 significantly influenced the phenotype and breeding value of sows for the number of piglets born and for the birth weight of piglets. Sows with the $A A$ genotype were characterized by a lower number of piglets born (by 8.0-8.5\%), and by a higher average birth weight (by 2.0-3.0\%). The significant effects of the ESR on TNB and NBA and on EBV values for birth weight were revealed: the sows of both breeds with $C C$ genotype for $E S R$ were characterized by highest average piglet weight at birth. We found the significant effect of MUC4 on birth weight of piglets for both breeds. Sows with $C C$ and $C G$ genotypes were superior comparing to individuals, which are homozygous for the $G$ allele. Thus, using the marker assisted selection along with traditional methods for assessing the genetic potential of pigs (BLUP AM) will significantly improve the efficiency of breeding measures on the fertility traits.

Keywords: pigs, Large White breed, Landrace, IGF2, ECR F18/FUT1, ESR, MUC4, linear regression, fertility traits, estimated breeding values, marker assisted selection.

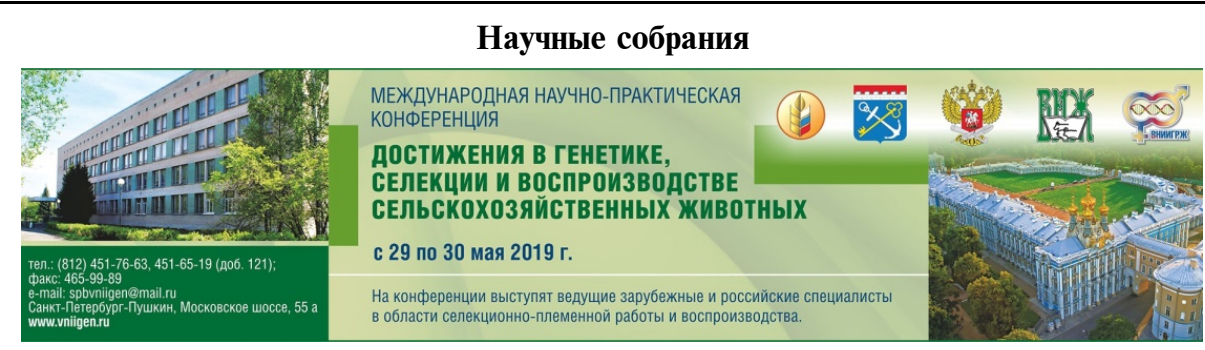

\section{МЕЖДУНАРОДНАЯ НАУЧНО-ПРАКТИЧЕСКАЯ КОНФЕРЕНЦИЯ «ДОСТИЖЕНИЯ В ГЕНЕТИКЕ, СЕЛЕКЦИИ И ВОСПРОИЗВОДСТВЕ СЕЛЬСКОХОЗЯЙСТВЕННЫХ ЖИВОТНЫХ»}

(29-30 мая 2019 года, г. Санкт-Петербург)

Конференцию, ставшую за несколько лет традиционной, каждый год посещают более 300 участников нескольких стран мира.

Конференция рассчитана на специалистов селекционно-племенной работы, зоотехников, ветеринарных врачей, ученых профильных организаций Минсельхоза РФ, научно-исследовательских институтов Министерства науки и высшего образования, высших учебных заведений (университетов) России, стран СНГ.

На конференции выступят ведущие зарубежные (Финляндия, Франция, Норвегия, Белоруссия, Казахстан) и российские специалисты в области селекционно-племенной работы и воспроизводства.

Тематика лекций включает в себя генетику и селекцию молочного и мясного скота, сельскохозяйственной птицы, методы криоконсервации и эффективного использования потенциала генетических ресурсов, интенсификацию воспроизводства, а также практический опыт работы генофондных и селекционных центров России.

Основные тематически направления:

- Биотехнологические методы в свиноводстве

- Разработка систем комплексной оценки племенной ценности по совокупности признаков молочной продуктивности

- Перспективы внедрения геномной оценки в племенное животноводство

- Гаплотипы фертильности

- Клеточные репродуктивные и ДНК-технологии

- Генетические аспекты криорезистентности спермы

- Репортирование генов

- Наследственные болезни и аномалии

В рамках конференции запланирована постерная сессия и мастер-классы по селекции, воспроизводству и геномике (отбор быков-производителей голштинской породы по комплексу признаков, методология получения эмбрионов животных in vitro, генетическое тестирование животных)

Информация: http://vniigen.ru/6403-2/ 